\title{
Exploration of intention to turnover: case study of hospital IT employees
}

\author{
Siska Ariani, Didik Setyawan \& Rudy Januar \\ Setia Budi University, Surakarta, Indonesia
}

Budi Setyanta

Janabadra University, Yogyakarta, Indonesia

\begin{abstract}
This study identifies factors that influence intentions for a turnover. Previous research indicated that hostile work environment, excessive workload, and job dissatisfaction are some factors that drive turnover intention. Data collection was done by survey method through a questionnaire. The sample of research was 120 employees of Information Technology (IT) department to qualify data analysis with Structural Equation Modeling (SEM). The results showed that organizational commitment, work fatigue, and job satisfaction directly affect turnover intention, while the autonomy and work characteristics indirectly influence the intention.
\end{abstract}

Keywords: intention to turnover, organizational commitment, work fatigue, job satisfaction

\section{INTRODUCTION}

The turnover intention of an organization attracts some studies (Ahuja et al. 2007, McKnight et al. 2009) and there is a diversity of factors that affect the intention (Moore \& Edwardsville 2000, Pare et al. 2001, Patrick 2003, Aydogdu \& Asikgil 2011). Previous research indicates that turnover intention is influenced by commitment (Pare et al. 2001), fatigue (Moore \& Edwardsville. 2000), and job satisfaction (Patrick 2003). The diversity indicates that there is no suitable model in different research settings. This study will explore the antecedents and consequences of organizational commitment, work fatigue, and job satisfaction on turnover intention.

\section{LITERATURE AND HYPOTHESIS}

Commitment is the employee's desire to stay in the organization (Hussain \& Asif 2012), which negatively affects the turnover intention of employees (Hsu, 2009, Aydogdu \& Asikgil 2011). It signifies the higher the employee's commitment to the organization, the lower the turnover intention. Eby et al. (1999) and Ahuja et al. (2007) identify that work autonomy positively affects organizational commitment. Work autonomy is an employee's license to organize its activities (McKnight et al. 2009), start, and perform their job to reduce stress on work (Ahuja et al. 2007) which shows the higher the work autonomy, the greater the organizational commitment.
H1: Organizational commitment negatively affects the turnover intention

$\mathrm{H} 2$ : Work autonomy has a positive influence on organizational commitment

Work fatigue is the perceived stress of workrelated individuals (Moore \& Edwardsville 2000), resulted from long working hours, organizational demands, and the drive to always improve work skills (LeRouge et al. 2006) that signifies the higher the work fatigue, the higher the turnover intention. Lack of work autonomy has an impact on an increase of work fatigue, due to employee stress increases (Maslach et al. 2001) the employees need to be given freedom in completing their work (Ahuja et al. 2007). McKnight et al. (2009) identify that work fatigue mediates the effect of work characteristics on turnover intention. Job characteristic is the behavior of individuals who are influenced by the response of the leadership to do something (Allen et al. 2008) that can reduce stress (Houkes et al. 2003).

H3: work fatigue has a positive effect on turnover intention.

H4: work autonomy negatively affects work fatigue. H5: job characteristics negatively affect work fatigue.

Job satisfaction is the individual's perception of his work (Dick et al. 2004), which negatively affects turnover intention (Lee 2002, Patrick 2003) that signifies the higher the job satisfaction, the lower the turnover intention. Job characteristics appropriate to a career, positively affect high job satisfaction (Lee 2002). 
H6: job satisfaction negatively affects turnover intention.

H7: job characteristic positively affects job satisfaction.

\section{RESEARCH METHOD}

The number of samples in this study was 120 employees of the IT department at hospitals in Solo City. Data collection was done through questionnaires with purposive random sampling technique, and data analysis used Structural Equation Modeling (SEM). Table 1 illustrates that organizational commitment has an adverse and significant effect on turnover intention so that the result supports hypothesis $1(\beta=-0.091$; S.E $=$ 0.071 ; C. $R=2.946$ ), which signifies that employees with high organizational commitment will be loyal and have lower turnover intention. This result supports previous research, which organizational commitment negatively affects turnover intention (Pare et al. 2001), so that it is an essential factor for loyal employees (Aydogdu \& Asikgil 2011).

\section{RESULT AND DISCUSSION}

Table 1. Result of SEM

\begin{tabular}{lccc}
\hline \multicolumn{1}{c}{ Hipotesis } & $\beta$ & S.E & C.R \\
\hline Intention $\leftarrow$ Commitment & -0.091 & 0.071 & 2.946 \\
Commitment $\leftarrow$ autonomy & 0.072 & 0.026 & -3.208 \\
Intention $\leftarrow$ Fatigue & 0.024 & 0.121 & 2.05 \\
Fatigue $\leftarrow$ autonomy & -0.224 & 0.093 & 2.258 \\
Fatigue $\leftarrow$ Characteristic & -0.01 & 0.148 & 3.568 \\
Intention $\leftarrow$ Satisfaction & -0.21 & 0.054 & -3.29 \\
Satisfaction $\leftarrow$ Characteristic & 0.018 & 0.052 & 2.578 \\
\hline
\end{tabular}

Work autonomy positively and significantly influences organizational commitment and this means that if employees obtain high work autonomy, then corporate responsibility will increase $(\beta=0.072$; S.E $=0.026 ;$ C $. R=-3.208$ ), meaning the result supports hypothesis 2 . This result supports previous research, which work autonomy positively affects organizational commitment (Eby et al., 1999) so that if employees obtain greater work flexibility, it will increase corporate engagement.

This study identifies that work fatigue increases employee's turnover intention, thus the intention increases if employee perception of occupational fatigue increases $(\beta=0.024 ; S . E=0.121 ; C . R=2.05)$, meaning the result supports hypothesis 3 . This study confirms previous research findings, which work fatigue has a significant positive effect on turnover in- tention (Moore \& Edwardsville 2000, Ahuja et al. 2007) thereby firms must perform workload analysis to identify reasonable workloads.

The results of this study indicate that work autonomy has an adverse and significant effect on work fatigue that means improving work autonomy can reduce work fatigue $(\beta=-0.224 ; \mathrm{S} . \mathrm{E}=0.093 ; \mathrm{C} . \mathrm{R}=$ 2.258 ), meaning the result supports hypothesis 4 . The results of this study confirm previous research, which work flexibility reduces frustration, work pressure, and fatigue (Houkes et al. 2001, Houkes et al. 2003, Kim \& Stoner 2008). Work fatigue is not only caused by long working time and excessive workload, but rigid work procedures can increase work fatigue. Therefore, organizations should develop working convenience procedures to reduce frustration and work stress.

Job characteristics refer to descriptions of work guidelines that affect job responsibilities, motivation, and performance. This study identifies that job characteristics have an adverse and significant effect on work fatigue $(\beta=-0.01 ; \mathrm{S} . \mathrm{E}=0.148$; C.R $=$ 3.568), meaning the result supports hypothesis 5 . This study supports previous research, which work safety and support from superiors and colleagues decrease job fatigue. That shows the more appropriate working characteristics, the lower the job fatigue. Proper job characteristics affect employee attitudes and work effectiveness, so the organization must develop the work attributes appropriately.

Job satisfaction is a feeling that supports or does not support a work-related employee. This study indicates that job satisfaction has an adverse and significant effect on turnover intention $(\beta=-0.21$; S.E = 0.054 ; $C . R=-3.29$ ), meaning the result supports hypothesis 6. Purposes of a turnover decrease, if employee's job satisfaction increases. Organizations must be able to provide a working atmosphere that can improve employee's job satisfaction, and lower turnover intention. This study supports previous research that advocates employee's high job satisfaction will lower turnover intention (Patrick 2003, Hsu 2009).

The results of statistical tests indicate that job characteristic have a significant positive effect on job satisfaction $(\beta=0.018 ; \mathrm{S} . \mathrm{E}=0.052 ; \mathrm{C} . \mathrm{R}=$ 2.578 ), meaning the result supports hypothesis 7 . That signifies the more appropriate the job characteristics, the higher the job satisfaction. A job characteristic is an approach to designing useful work in specific work situations that affect employee attitudes and behavior in the workplace. Job satisfaction is the result of employee interaction within the working environment and employee expectations of work and office. That is an attitude to appreciate his work, through morale of work, discipline and work per- 
formance. The organization to improve employee satisfaction, the team establishes job characteristics that can enhance work motivation. This study supports previous research, utilizing skills and providing feedback to employees has an effect on job satisfaction (Dick et al. 2004, Aydogdu \& Asikgil 2011).

\section{CONCLUSION}

This study indicates that individual attitudes to survival in the organization, work fatigue, and employee's job satisfaction affect turnover intention. In order to keep critical employees from turnover, the organization must increase organizational commitment by establishing the values and objectives that employees can accept. While to reduce turnover, the organization should create a comfortable working atmosphere, manage conflict, perform work rotation, workload analysis to minimize work fatigue, and improve job satisfaction. This study also indicates that job characteristics and work autonomy indirectly influence turnover intention.

\section{REFERENCES}

Ahuja, M.K., Chudoba, K.M. \& Kacmar C.J. 2007. IT Road Warriors: Balancing Work-Family Conflict, Job Autonomy, and Work Overload to Mitigate Turnover Intentions, MIS Quarterly 31(1): 1-17.

Allen, W.M., Armstrong, D.J., Reid, M.F. \& Riemenschneider C.K. 2008. Factors Impacting the Perceived Organizational Support of IT Employees, Information \& Management 45: $556-563$.

Aydogdu, S \& Asikgil, B. 2011. An Empirical Study of the Relationship Among Job Satisfaction, Organizational Commitment and Turnover Intention, International Review of Management and Marketing 1(3): 43-53.

Dick, R.V., Christ, O., Stellmacher, J., Wagner, U., Ahlswedew, O., Grubbaw, C., Hauptmeier, M., Hohfeld, C., Moltzen, K. \& Tissington, P.A. 2004. Should I Stay or Should I Go? Explaining Turnover Intentions with Organizational Identification and Job Satisfaction, British Journal of Management 15: 351-360.

Eby, L. T., Freeman, D. M., Rush, M. C. \& Lance, C. E. 1999. Motivational Bases of Affective Organizational Commitment: A Partial Test of an Integrative Theoretical Model, Journal of Occupational and Organizational Psychology 72: 463-483.

Houkes, I. Janssen, P. P.M., Jonge, J. D. \& Nijhuis, F.J.N. 2001. Specific Relationships Between Work Characteristics and Intrinsic Work Motivation, Burnout and Turnover Intention: A Multi-Sample Analysis, European Journal of Work And Organizational Psychology 10 (1): 1-23.

Houkes, I., Janssen, P. P.M., Jonge, J. D. \& Bakker, A. B. 2003. Specific Determinants of Intrinsic Work Motivation, Emotional Exhaustion and Turnover Intention: A Multisampling Longitudinal Study, Journal of Occupational and Organizational Psychology 76: 427-450.
Hsu, H.Y. 2009. Organizational Learning Culture's Influence on Job Satisfaction, Organizational Commitment, and Turnover Intention Among R\&D Professionals in Taiwan during an Economic Downturn, Dissertation. Unpublished.

Hussain, T. \& Asif, S. 2012. Is Employees' Turnover Intention Driven by Organizational Commitment and Perceived Organizational Support, Journal of Quality and Technology Management 8(2): 1-10.

Kim, H. \& Stoner, M. 2008. Burnout and Turnover Intention Among Social Workers: Effects of Role Stress, Job Autonomy and Social Support, Journal Administration in Social Work 32: 5-25.

Lee, A.W. 2002. Career Anchors of United States Air Force Information Systems Workers: A Turnover Predictor, Approved for Public Release; Distribution Unlimited. Thesis. Unpublished.

LeRouge, C., Nelson, A., Blanton, J. E. 2006. The Impact of Role Stress Fit and Self-esteem on The Job Attitudes of IT Professional, Information \& Management 43: 928-938.

Maslach, C Schaufeli, W. B., Leiter, M. P. 2001. Job Burnout. Annual Review of Psychology 52: 397-422.

McKnight, D. H, Phillips, P. \& Hardgrave, B. C. 2009. Which Reduces IT Turnover Intention the Most: Workplace Characteristics or Job Characteristics, Information \& Management 46: 167-174.

Moore, J.E. \& Edwardsville. 2000. One Road To Turnover: An Examination Of Work Exhaustion In Technology Professionals, MIS Quarterly 24(1): 141-168.

Pare, G., Tremblay, M. \& Lalonde, P. 2001. The Role of Organizational Commitment And Citizenship Behaviors In Understanding Relations Between Human Resources Practices And Turnover Intentions Of It Personnel, Cahier $d u$ GReSI. (01-07).

Patrick, C.B.L. 2003. Social Support and Leaving Intention Among Computer Professionals, Information \& Management 41: 323-334. 